Przegląd Antropologiczny 1986 , tom 52, z. 1-2, s. 55-68, Poznań 1988

https://doi.org/10.18778/1898-6773.52.1-2.05

\title{
Antropologia a nauki stosowane. Antropologia polska nadchodzących lat
}

\author{
Zbigniew Drozdowski
}

ANTHROPOLOGY AND APPLIED SCIENCES. POLISH ANTHROPOLOGY OF THE COMING YEARS. An analysis of the connections of anthropology with different fields of social and economic practices permits to outiline a perspective of the future development of this science.

\section{Wstẹp}

Podobnie, jak to ma miejsce w przypadku wielu naukowych dyscyplin, tradycja każe upatrywać narodzin antropologii w starożytnej Grecji. Termin ten bowiem pierwszy raz spotykamy u Arystotelesa ze Stagiry, a rozumial on poprzez niego przede wszystkim badanie psychicznych wlaściwości czlowieka, lecz zajmowal się również charakterystyką jego cech fizycznych. Początkowo polączona z innymi naukami badającymi czlowieka stopniowo zarysowywala antropologia swoją specyficzność, wyróżniającą ją spośród innych dyscyplin. W polowie ubieglego wieku wyodrębnila się w samodzielną dyscyplinę o stosunkowo szerokim zakresie badań zresztą utrzymującym się $w$ niektórych środowiskach do czasów wspólczesnych.

Zakład Antropologii Sportu AWF ul. Marchlewskiego 27/39, 61-871 Poznań
Ujmowala szeroki wachlarz informacji o fizycznych i spoleczno-kulturowych wlaściwościach czlowieka i ludzkiej populacji, czy jej różnych zespolów. Proces ten szczególnie zaznaczyl się $\mathrm{w}$ połowie ubieglego wieku, stąd też przyjmujemy, że jest to okres narodzin nowoczesnej antropologii, jednak jej zakres i profil dzialania byly stopniowo modyfikowane.

Rozumiejąc antropologię jako naukę o czlowieku, twórca jej nowoczesnego ksztaltu - Pawel BROCA - przyjmowal ją jako "naukę zajmującą się badaniem rodzaju ludzkiego jako całości z uwzględnieniem jego części i stosunku do pozostalej przyrody" [CZEKANOWSKI 1930]. Proces jej przeksztalceń J. CZEKANOWSKI [1948] ujmuje następująco: "...dawne porównawczo-anatomiczne ujęcie, odzwierciedlające się w definicji Broca, ustępowało nowemu ześrodkowującemu antropologię na badaniu czlowieka jako podłoża zjawisk spolecznych. W ten sposób przesu- 
wano się od rozpatrywania czlowieka w perspektywie czasu biologicznego do badania go w perspektywie czasu socjologicznego ..." (s. 9-10).

Zarysowuje się zatem rozumienie antropologii jako nauki mającej swój obszar badawczy na pograniczu biologicznych i spolecznych form ruchu materii, przy uwzględnieniu również innych - abiotycznych jego postaci. Wprowadza to antropologię w system szczególnie licznych i złożonych jej powiązań $z$ innymi naukowymi dyscyplinami [CZEKANOWSKI 1930, 1948; DROZDOWSKI 1973; DZIERŻYKRAYRogalsKI, CHARZEWSKI 1978; SEDLAK 1980; WIERCIŃSKI 1980, 1984].

Adam WRZOSEK [1926], twórca poznańskiego ośrodka antropologicznego i organizator polskiej antropologii, widzial wspomniane powiązania następująco: "Za nauki podstawowe antropologii należy zdaniem moim uważać nie tylko anatomię, fizjologię, psychologię, anatomię patologiczną, patologię ogólną i doświadczalną oraz psychopatologię, lecz również biologię ogólną $\mathrm{i}$ anatomię porównawczą, a za glówne nauki pomocnicze - nie tylko geografię, geologię, paleontologię, prehistorię, historię, językoznawstwo, etnografię, etnologię i historię kultury, lecz także fizjologię porównawczą, histologię i bakteriologię, a zwlaszcza dzial jej - serologię ...". Wprawdzie poglądy te ulegly określonym modyfikacjom, lecz pozostaly $w$ pelni aktualne $w$ ich najbardziej istotnym fragmencie, stawiającym antropologię na pograniczu nauk przyrodniczych i spolecznych. Znalazly pelne potwierdzenie w rozumieniu dyscypliny przez polską szkolę antropologiczną. Jej twórca - Jan CZEKANOWSKI [1948a,b] formulowal antropologię jako naukę badającą czlowieka jako biologiczne podłoże zjawisk spolecznych. Także radzieccy antropolodzy M.G.
LEVIN i J.J. RoGINSKIJ [1951] podzielają zbliżone rozumienie antropologii, precyzując następująco jej zadania: "Zadaniem antropologii jest prześledzenie procesów przejścia od prawidlowości biologicznych, którym przyporządkowane bylo istnienie zwierzęcych przodków czlowieka, do prawidłowości socjalnych. W ten sposób antropologia zajmuje w kręgu nauk biologicznych miejsce szczególne. Biorąc za przedmiot swego badania czlowieka, nie może ona wyjść poza granice zagadnień przyrodniczych, badając natomiast istotę czlowieka wchodzi w dziedzinę wiedzy, gdzie dzialają czynniki historyczno-socjalne. $Z$ tej sytuacji pogranicza antropologii do różnych nauk wyplywa jej stosunek do nauk pokrewnych. Będąc nierozerwalnie związana $z$ licznymi galęziami nauk przyrodniczych, jednocześnie stoi bardzo blisko nauk spolecznych. W tym znaczeniu antropologia stanowi koronę nauk biologicznych".

Taki kierunek rozwoju wspólczesnej antropologii prowadzil do przyjęcia przez polskich antropologów w toku przygotowań II Kongresu Nauki Polskiej poglądu, że "antropologia jest nauką badającą czlowieka jako biologiczne podłoże zjawisk spolecznych, a także biologiczne skutki tych zjawisk przejawiające się w jego organizmie oraz ludzkiej populacji" [DROZDOWSKI 1973; DROZDOWSKI, DZIERŻYKRAY-ROGALSKI 1982].

Do takiego rozumienia swego ksztaltu dążyla antropologia polska od 1856 r., kiedy Józef Majer - wobec zakazu wykładów w języku polskim na uniwersytecie w Krakowie - podjąl wykladanie tej dyscypliny w języku polskim, jako nieobowiązkowej. Dynamiczny rozwój polskiej ant ropologii w międzywojennym okresie znalazl wyraz w uksztaltowaniu się oryginalnych naukowych szkól i kierunków badawczych, 
mianowicie warszawskiej szkoly anatomiczno-porównawczej Edwarda Lotha, Iwowskiej szkoly antropologicznej (dzisiaj zwanej polską szkolą antropologiczną) Jana Czekanowskiego, krakowskiego kierunku morfologicznego Kazimierza Stolyhwy oraz poznańskiego ośrodka porównawczo-rozwojowej biologii czlowieka Adama Wrzoska.

Okres ten cechuje bardzo silne powiązanie antropologii $\mathrm{z}$ innymi dyscyplinami naukowymi, co w pewnej mierze wynikało $z$ zarysowującego się dopiero odrębnego ksztalcenia antropologów. Nie przyniósl jednak ten okres dostatecznie zwartego programu rozwoju polskiej antropologii, a tylko jego zarys znalazl wyraz w programach dzialania Polskiego Towarzystwa Antropologicznego. Proces ten w znacznej mierze utrudnily straty, jakie poniosia polska antropologia w czasie wojny. Pierwszy kompleksowy program dyscypliny zarysowano na przelomie lat 1950/51 w toku przygotowania I Kongresu Nauki Polskiej, a rozwinięto w późniejszych latach [MYDLARSKI 1951, 1952; Nauki antropologiczne ... 1979; Sprawozdanie ... 1975-77; Stan antropologii ... 1977]. Znamienne jest, że w programach tych wyraźnie zarysowano wspóldzialanie antropologów z przedstawicielami różnych dyscyplin naukowych w poznawaniu biologicznej zmienności czlowieka ujmowanej w czasie i przestrzeni. W poczynaniach tych wzbogacała się zarówno problematyka antropologiczna w zakresie stosowanych metod i technik badawczych, jak też pojawialy się nowe problemy, często otwierające wielce oryginalne obszary naukowego poznania. Prowadzilo to do konieczności okresowej refleksji nad tendencjami rozwoju dyscypliny i jej miejscem w rzędzie nauk, szczególnie zajmujących się czlowiekiem i ludzką populacja. Wspomniane prace i poczyna- nia badawcze oraz organizacyjne, wynikające $z$ zadań zarysowanych polskiej antropologii, stanowily do tego szczególną okazję. Jest nią również ustalenie tematu wiodącego dla zjazdu z okazji 60-lecia Polskiego Towarzystwa Antropologicznego: "Antropologia i jej miejsce wśród nauk o czlowieku". Naszym rozważaniom wyznaczono zadanie rozsądzenia kwestii "antropologia a nauki stosowane". Bliższe jednak głównemu problemowi, a nie różniące się od przytoczonego zadania, byłoby sformulowanie odpowiedzi na następujące pytania: 1) jakie jest miejsce antropologii $w$ rzędzie innych nauk dni dzisiejszych, w tym szczególnie nauk o czlowieku, 2) jakie glówne problemy badawcze nur tują wspólczesną antropologię i $\mathrm{z}$ jakimi dyscyplinami naukowymi $\mathrm{w}$ ich rozwiązywaniu wspóldziala, 3) jakie przeslanki będą wyznaczaly dalszy rozwój antropologicznej problematyki, 4) jakie, w związku z nimi, problemy staną się szczególnie ważne i $z$ jakimi dyscyplinami naukowymi wspóldziałanie w ich rozwiązywaniu będzie konieczne, 5) czym antropologia może slużyć innym dyscyplinom szczególnie z nią wspóldzialającym - oraz czego sama od nich oczekuje, 6) jakie miejsce można by wyznaczyć antropologii w formule nadchodzącej cywilizacji XXI wieku.

\section{Antropologia - miejsce w rzędzie innych nauk}

Dokonując wprowadzenia do podjętego tematu scharakteryzowaliśmy wyżej drogę rozwoju antropologicznej problematyki oraz, w historycznym przekroju, jej definicyjne określenia. Gwoli kompletności rozważań przyjmujemy podzial obszaru naukowej wiedzy na nauki formalne, 
fizyczne, biologiczne i spoleczne. Antropologia leży, przy takim podziale, w sferze nauk biologicznych, co znajduje często wyraz w przyjmowaniu pojęcia "antropologia fizyczna" w odróżnieniu od antropologii kulturowej, wchodzącej do grupy nauk spolecznych. Ponieważ w naszych rozważaniach będziemy traktowali wylącznie o antropologii fizycznej, nie popełnimy blędu opuszczając jej przymiotnikowe określenie. Antropologia znajduje się w lańcuchu dyscyplin naukowych najbliżej nauk spolecznych, co pozwala traktować ją jako dyscyplinę pograniczną. Wedlug opracowań Komitetu Antropologii PAN na III Kongres Nauki Polskiej [BERgMAN i in. 1985] możemy przyjąć, że "antropologia jest nauką badającą czlowieka jako biologiczne podłoże zjawisk spolecznych, a także biologiczne skutki tych zjawisk występujące u osobnika iw ludzkiej populacji. Należy podkreślić, że zjawisko spoleczne rozumiemy w tym przypadku w szerokim znaczeniu - zarówno jako proces wielopokoleniowy, składający się na przemiany ewolucyjne, czy mikroewolucyjne, jak też doraźne oddzialywania zostawiające ślad adaptabilny, czy adiustacyjny. W tym rozumieniu ujmujemy biologiczne skutki spolecznych procesów".

Glówne problemy badawcze wspólczesnej antropologii polskiej i dyscypliny wspóldzialające $w$ ich realizacji

Korzystając z materialów na III Kongres Nauki Polskiej moźemy przyjąć, że badawcze poszukiwania polskich antropologów koncentrowały się w minionych latach na następujących zagadnieniach.

A. W zakresie nauk ontogenetycznych: 1) kontynuowano dokumentowanie i analizę zmian, jakim podlega polska populacja w wyniku przemian społeczno-ekonomicznych i ekologicznych zachodzących w kraju i na świecie, 2) badano spoleczne znaczenie zmian sekularnych oraz akceleracji dojrzewania dla dalszych losów życiowych jednostki, 3) śledzono tempo inwolucyjnych przemian w zakresie różnych cech biologicznych, 4) badano genetyczne uwarunkowania przebiegu i tempa wzrastania w okresie pokwitania. W realizacji tej problematyki wspóldzialala antropologia $\mathrm{z}$ anatomią, fizjologią, ekologia, biometeorologią, genetyka, socjologią, psychologią, pediatrią i gerontologia, naukami o żywieniu. Uzyskane wyniki składały się $\mathrm{w}$ sferze poznawczej na rozwinięcie wiedzy o biologii czlowieka, jego biospolecznym rozwoju oraz różnorodnych jego uwarunkowaniach. W sferze zastosowań natomiast uzyskiwane wyniki slużyly racjonalizacji procesu edukacji, organizacji pracy zawodowej i wypoczynku, a także byly wykorzystywane w różnych relacjach przez nauki medyczne, pedagogiczne, nauki o wychowaniu fizycznym [BIELICKI 1981, 1984; Nauki antropologiczne ... 1979; Stan antropologii ... 1977; STĘŚLICKAMYDLARSKA 1976, PIASECKI 1977].

B. W zakresie antropologii historycznej: 1) kontynuowano prace wykopaliskowe dla zabezpieczenia osteol ogicznych materialów do dalszych szczególowych analiz, 2) kontynuowano badania przemian mikroewolucyjnych w procesie poznawania biologii populacji pradziejowych, 3) wspóldziałano problematyką antropologiczną w rozwiązywaniu różnych zagadnień etnogenetycznych. W realizacji przytoczonych prac współdzialano szczególnie $\mathrm{z}$ archeologami, historykami, demografami, a uzyskiwane wyniki slużyly do rekonstrukcji różnych procesów historycznych, demograficznych przemian i poznania biologii populacji pradziejowych [HENNEBERG 1978; 
MALINOWSKI 1976; PIONTEK 1978, 1979, 1985; STRZALKO 1978, 1980; STRZALKO, HENNEBERG, PIONTEK 1980; WIERCIŃSKI 1980, 1984].

C. W zakresie ekologii czlowieka kontynuowano śledzenie zmian zachodzących w biologicznej wartości populacji zamieszkujących $\mathrm{w}$ środowiskach zmienianych działalnością czlowieka. Badawcze poszukiwania w tym zakresie mają szczególne spoleczne znaczenie, a w antropologicznej problematyce znajdowały się niemal od zaczątków dyscypliny w Polsce, zyskując syntetyzujące ujęcie pod koniec okresu międzywojennego [Czlowiek, jego rasy $i$ zycie 1938]. W realizacji przyjętych na siebie w tym zakresie zadań antropologowie współdzialali z ekologami, biometeorologami, socjologami, ekonomistami, aw wielu przypadkach także z przedstawicielami nauk techniczych. Wyniki prac badawczych wchodzily do różnych ekspertyz i opinii - w tym również przygotowywanych dla organów kierowniczych kraju i jego poszczególnych regionów [BIELICKI 1981; DrozDOWSKI 1980; STRZALKO 1980; WOLAŃSKI 1975, 1981].

D. W zakresie antropologii sportu: 1) kontynuowano badania stanu rozwoju fizycznego i motorycznego polskiej populacji wraz z uwarunkowaniami tego procesu, 2) badano morfo-funkcjonalne uwarunkowania różnych form aktywności fizycznej czlowieka, ze szczególnym uwzględnieniem aktywności sportowej, 3) badano zmiany morfofunkcjonalne zachodzące $w$ ludzkim organizmie pod wplywem różnych form aktywności fizycznej, bądż też jej braku. Obok ścisłego wspóldziałania z naukami o kulturze fizycznej, w realizacji tej problematyki wspóldziałano szczególnie $\mathrm{z}$ funkcjonalną anatomią, fizjologią sportu, socjologią i genetyką. Uzyskane wyniki na trwale weszly do teoretycznych podstaw kultury fizycznej [DROZDOWSKI 1983 a,b,c; GODYCKI 1959], lecz byly wykorzystywane także w ergonomii, pedagogice, $w$ zawodowym poradnictwie.

E. Antropogeneza - byla badana przez polskich antropologów w ostatnich latach w mniejszym zakresie, przy koncentracji raczej na problematyce teoretycznej i metodologicznej; kontynuowano badania dotyczące odtwarzania oblicza czlowieka kopalnego i jego ewolucyjnych przodków. Szczególnie ostatnie lata przyniosly $w$ badaniach antropogenezy wspóldzial ania z ekologami, prymatologami, psychologamii socjologami, a także etologami. Uzyskane wyniki mają istotne filozoficzne znaczenie. Brak wlasnych materialów kopalnych z wczesnych etapów ewolucji naszych przodków nadaje polskim pracom badawczym $w$ tym zakresie specyficzny ksztalt [BIELICKI 1969, STĘŚLICKA-MYDLARSKA 1976, STRZALKO 1978, STRZALKo, HenNEBERG, PIONTEK 1980; WIERCIŃSKI 1984].

F. Paleopatologia - rozwijała się bardzo dynamicznie, przy koncentracji na: 1) materialowym dokumentowaniu zjawisk paleopatologicznych w populacjach wymarlych, 2) wspóldzialaniu z paleodemografami. Sciśle wspólpracują antropologowie zajmujący się tą problematyką $z$ anatomami, patologami, archeologami i demografami. Uzyskane wyniki mają glównie walor poznawczy, pozwalając uzupełnić rekonstrukcję wielu spolecznych procesów epok minionych, lecz wyjaśniają również mechanizm różnych mikroewolucyjnych przemian, które nie są obojętne także dla wspólczesnego czlowieka i tworzonego przezeń spoleczeństwa [DZIERŻYKRAYROGALSKI 1978, GLADYKOWSKARZECZYCKA 1979].

Praktyczne zastosowania antropologii znajdowaly wyraz $w$ przygotowywaniu 
różnych ekspertyz - tak o ogólnym charakterze, jak też bardzo szczególowym. Niezależnie od potocznych w tym względzie opinii należy wymienić opracowanie dla potrzeb przemysłu standardów odzieży, sprzętu codziennego użytku i narzędzi pracy. Wykonano dla różnych zakladów produkcyjnych ekspertyzy dotyczące zagospodarowania przestrzeni pracy. Tradycyjny jest już udział antropologów w ekspertyzach sądowych dotyczących dochodzenia ojcostwa, zwiększa się także wspólpraca $z$ medycyną sądową. Upowszechniono również normy rozwoju dziecka, zresztą ciągle doskonalone i szeroko wykorzystywane w pracy lekarzy szkolnych, higienistów, nauczycieli wychowania fizycznego. Zdajemy sobie sprawę z roli, jaką może i powinna antropologia spelniać informując spoleczeństwo i jego organy kierownicze o biologicznych skutkach przemian, jakim podlega ludzka populacja.

Podkreślić także należy, że więzi antropologii z innymi dyscyplinami naukowymi są również realizowane poprzez proces dydaktyczny. Problematyka antropologiczna - w różnym zakresie i wymiarze - jest wykladana na studiach biologicznych, kultury fizycznej, archeologicznych, etnograficznych, pedagogicznych, psychologicznych, medycznych, zarówno przeddyplomowych, jak też w toku doskonalenia kadr. Zagadnienia antropologii, a szczególnie techniki i metody badawcze antropologii, są szeroko wykorzystywane na różnych kierunkach studiów przy wykonywaniu rozpraw tak na stopnie zawodowe, jak też naukowe. Upowszechniając problematykę antropologiczną proces ten przyczynia się do wiązania antropologii $\mathrm{z}$ innymi naukowymi dyscyplinami, zresztą nie tylko leżącymi na jej obrzeżu [BERGMAN $i$ in. 1985; DROZDOWSKI 1979; MALINOWSKI 1979; $\mathrm{Na-}$ uczanie Antropologii 1979; NoWAK 1978].
Przesłanki rozwoju antropologicznej problematyki badawczej nadchodzących lat

Jako dyscyplina naukowa podlega antropologia tym samym ogólnym czynnikom, które wyznaczają rozwój nauki. Wydaje się jednak, że niektóre z nich mogą być szczególnie ważkie dla niej. Można wymienić wśród nich następujące: a) narastające społeczne zainteresowanie biologicznymi skutkami przemian, jakim podlega ludzka populacja w wyniku zmian zachodzących $w$ natural nym (przyrodniczym) środowisku, a także w środowisku spolecznym, b) wzrost zainteresowania biologicznymi wlaściwościami czlowieka, jego zmiennością, narastające zainteresowanie ludzką populacją, jej regionalnym zróżnicowaniem, co jest między innymi wynikiem rozszerzających się możliwości poznania populacji odleglych, c) rosnąca intensyfikacja pracy skłania do szukania różnych biospolecznych przesłanek skladających się na zwiększanie produkcyjnych możliwości i twórczych zdolności czlowieka, ochrony jego biospolecznego potencjału oraz przyspieszenia procesu odnowy sil biologicznych i twórczych zdolności, w czym antropologia może stać się dyscypliną szczególnie znaczącą [BERGMAN $\mathrm{i}$ in. 1985].

Główne kierunki antropologicznych prac badawczych lat nadchodzących i dyscypliny współdziałające $w$ ich realizacji

Wszelkie prognozy w dynamicznie zmieniającym się współczesnym świecie są utrudnione, a już szczególnie odnosi się to do przewidywania rozwoju nauki. Dyscypliny leżące na pograniczu różnych sfer wiedzy naukowej, o kompleksowym ksztalcie - do takich zaliczyliśmy wyżej antropologię - są 
w tym względzie w sytuacji szczególnie zlożonej. Pewne przybliżenie można jednak uzyskać, a stopień jego dokladności określić uwzględniając ogólne tendencje spolecznego rozwoju. Uwzględniając przytoczone zastrzeżenia, wydaje się, że glówne kierunki rozwoju antropologii jako badawczej dyscypliny można sprowadzić do następujących.

A. W zakresie metod badawczych wydaje się, że do swego dzialania wlączy antropologia szereg nowych badawczych metod związanych z ogólnym postępem wiedzy, a będących "na wyposażeniu" nauk fizjologicznych i socjologicznych. Szczególnego jednak postępu należy oczekiwać we wzbogaceniu antropologicznych technik pomiarowych. Prawdopodobnie nastąpi szersze aniżeli to ma miejsce dotąd wlączenie nowoczesnych sposobów badania biochemicznych wlaściwości ludzkiego organizmu, jego funkcjonalnych charakterystyk i zachodzących w nich zmian w procesie różnorodnych obciążeń. Wielce obiecujące są $w$ tym względzie technikı związane $z$ miniaturyzacją urządzeń i pobieranych prób biologicznego materialu oraz wszelkie techniki telemetryczne do badania przebiegu procesów. W zakresie morfologii należy oczekiwać przesunięcia zainteresowania na badania wielkości, ksztaltu itp. różnych organów wewnętrznych, do czego mogą być przydatne techniki radiologiczne i tomograficzne. Powrót antropologii do szerszego wspóldzialania z naukami spolecznymi pozwala spodziewać się znaczniejszego wykorzystania ich technik i metod badawczych, wlącznie do bardziej złożonych, socjometrycznych. Wreszcie w opracowywaniu pozyskanych materialów istotną pomoca będzie szersze zastosowanie komputerów, co pozwoli na doskonalsze opracowanie antropologicznej informacji, jak też zastosowanie bardziej wyrafi- nowanych metod statystycznych. Jest to o tyle ważne, że antropologia inicjująca i wiodąca przez dlugie okresy w zastosowaniach statystycznych metod $w$ poczynaniach badawczych, traci obecnie swój prymat w tym względzie, co przy ogólnym postępie wiedzy $w$ pewnym momencie może stać się ograniczeniem postępu.

B. Tradycyjne dla antropologii badania ontogenetyczne będą utrzymywaly się, lecz przy pewnym przesunięciu akcentów. Wydaje się, że najpelniej spodziewany kierunek badań można ująć tematem "biologiczna wartość polskiej populacji i jej uwarunkowania zmieniającymi się czynnikami środowiska". Należy penetracją antropologów w szerszym zakresie objąc morfologiczną i funkcjonalną zmienność calego postembrionalnego rozwoju czlowieka. Rosnąca wartość ludzkich zespolów w wieku produkcyjnym (wobec oczekiwanego zmniejszenia ich udzialu procentowego w polskiej populacji) nasuwa w tym względzie szczególne zadania praktyczne. Także narastający w polskim spoleczeństwie udzial osobników w wieku poprodukcyjnym stwarza rozszerzające się pole badawcze antropologii, związane $z$ doskonaleniem informacji o procesach starzenia. Sądzę, że szczególne znaczenie dla antropologii w nachodzących latach winny mieć badania różnych fizjologicznych (w tym również biochemicznych) wlaściwości ludzkiego organizmu, lecz ujmowanych populacyjnie, a także $w$ postaci badań longitudinalnych (szczególnie istotne $w$ stosunku do osobników w wieku starczym). Wobec narastającej komplikacji uwarunkowań zmienności ludzkiego organizmu należy oczekiwać szerszego włączenia do antropologicznych badań problematyki ekologicznej, w tym szczególnie spolecznej. Trudno obecnie ustalić, w jakiej mierze antropologia włączy do 
swego dzialania badania procesów przemian psychicznych i spolecznych, lecz jest niewątpliwe szersze wykorzystywanie informacji z tego zakresu dawanych przez inne specjalistyczne dyscypliny naukowe (socjologia, psychologia itp). Nowym problemem w tym zakresie, wymagającym pilnego podjęcia ze względu na jego znaczenie, jest poznanie biologicznych uwarunkowań różnych spolecznych zjawisk, które byly dotąd dość nieśmialo sygnalizowane. Antropologia ze względu na jej kompleksowe ujęcie jest szczególnie predestynowana do rozwijania badań w tym zakresie. Mogą one być zbieżne z poszukiwaniami biopolityki zajmującej się analizą biologicznych uwarunkowań predyspozycji i zachowań politycznych [WIATR 1985]. Swoje miejsce będą mialy niewątpliwie w tym cyklu także prace podejmowane we wspóldzialaniu $z$ etologią i socjobiologią, przy znacznym zazębianiu się zakresów w niektórych kwestiach. Może antropologia przyczynić się do rozproszenia wielu nieporozumień i uprzedzeń towarzyszących badaniom tych dyscyplin w ludzkiej populacji. W realizacji przytoczonych kwestii badawczych antropologia będzie wspóldzialala zarówno z naukami biologicznymi (anatomia, fizjologia, genetyka), jak też spolecznymi (socjologia, psychologia i pedagogika, ekonomia, nauki polityczne), korzystając również z calego bloku nauk medycznych, nauk o kulturze fizycznej i ergonomii.

C. Badania morfofunkcjonalnych uwarunkowań powodzenia w różnych formach fizycznej aktywności czlowieka można najzwięźlej ująć tematem "biospoleczne uwarunkowania fizycznej i spolecznej aktywności czlowieka oraz ludzkiej populacji". Badania w tym zakresie w znacznej mierze uzupełniają i zazębiają się z poszukiwaniami dotyczącymi biologicznej wartości ludz- kiej populacji. Prace dotyczące tego problemu mają w polskiej antropologii swoją tradycję w jej zastosowaniach w naukach o kulturze fizycznej, szczególnie w sporcie, stwarzając przesłanki stosunkowo dobrego doboru i selekcji osobników w różnych sportowych dyscyplinach i konkurencjach. Lata ostatnie przyniosty powrót - w udoskonalonej formie - badań morfologicznych uwarunkowań powodzenia w różnych zawodach, w tym szczególnie wymagających zwiększonej aktywności fizycznej. Rosnąca wartość wysoko wykwalifikowanego pracownika szczególnie aktualizuje ten zakres badań, rozszerzając go o poznawanie morfofunkcjonalnych skutków zwiększonej aktywności fizycznej, co prowadzi do stworzenia podstaw dzialalności rekompensującej, szczególnie oddziaływania negatywne. $Z$ tym zakresem wiążą się dociekania dotyczące skutków obniżonej aktywności fizycznej, jej uwarunkowań idą te prace w parze $\mathrm{z}$ badaniami zespolów osobników zapadających na różne schorzenia. W przytoczonych zakresach należy oczekiwać zintensyfikowania badań morfologii ludzkiego ciała, zmian fizjologicznych, ujmowanych przy uwzględnieniu substratu spolecznego. Szczególne wspóldziałanie winno występować z całym zespolem nauk medycznych (przede wszystkim z medycyną pracy i medycyną szkolną), z ergonomią i naukami o kulturze fizycznej. W tradycyjnym ujęciu antropologii prace te znalazly swoje miejsce $w$ antropologii lekarskiej, antropologii sportu, antropometrii inżynieryjnej czy przemysłowej.

D. Prace badawcze dotyczące biologii populacji pradziejowych, ze względu na spodziewany kierunek poszukiwań oraz wykorzystanie ich wyników, najbardziej oddawalby temat "Biologia populacji pradziejowych a procesy etnogenezy". Rozwój nowoczesnych technik badawczych 
niewątpliwie rozszerzy zakres tradycyjnych poszukiwań opieranych na klasycznych osteologicznych wzorcach analizy. Obok kontynuacji badań cmentarzysk (przy pelnym wspóldzialaniu $\mathrm{z}$ archeologami i historykami sztuki) dla pozyskiwania materialów osteologicznych, należy spodziewać się prac ukierunkowanych na poznanie budowy ciała osobników $\mathrm{z}$ wymarlych populacji, biospolecznych uwarunkowań ich życia i rekonstrukcji zjawisk demograficznych. Uzyskiwane materialy $\mathrm{i}$ otrzymane na ich podstawie poznawcze wyniki dają także obraz zjawisk patologicznych, mających miejsce w pradziejowych populacjach. Poznanie struktury wymarlych populacji, warunków ich życia, uchwycenie mikroewolucyjnych przemian czlowieka, a także ich uwarunkowań, to glówne z oczekiwanych wyników. Pozwolą one na rekonstrukcję środowiska, w którym żyli nasi przodkowie, trybu ich życia, bytowych warunków, a na tym tle biologicznej dynamiki. We wspóldzialaniu $z$ archeologami, paleodemografami, patologami, historykami, przyczyni się antropologia do rozwiklania kolejnych kwestii dotyczących różnych procesów etnogenezy, mających miejsce w ludzkiej populacji. Podkreślić należy poznawczą wartość prowadzonych prac w omawianym zakresie.

E. Badania filogenezy czlowieka, będące klasycznym wlasnym obszarem badań antropologii, mają szczególne znaczenie, dostarczając budulcowego materialu filozofii i niosąc znaczny światopoglądowy ladunek. $\mathrm{Ze}$ wspomnianych przyczyn polskie prace w tym zakresie będą prawodopodobnie przesuwaly się nadal $w$ kierunku ogólnej teorii antropogenezy, przy wykorzystaniu wlaściwych polskiej antropologii metod i technik analitycznych. Gwoli pelni informacji należy zwrócić uwagę na odradzające się badania dotyczące antropomorfologii części miękkich, mające w polskiej antropologii szczególne tradycje. Uzyskiwane w tym względzie wyniki, szczególnie związane $z$ pracami dotyczącymi genezy ukladu ruchu, mogą dostarczyć wielu cennych informacji istotnie wzbogacających materialy związane $\mathrm{z}$ ogólną teorią antropogenezy. Móglby to być nowy oryginalny kierunek prac, których wyniki wykraczalyby zresztą poza antropogenezę.

F. Zastosowania antropologii, jak to już podnosiliśmy, mają swoją tradycję. We wspomnianych już materialach na III Kongres Nauki Polskiej znajdujemy w tej sprawie następujące informacje: "Szczególnie ważne i pilne wydają się następujące opracowania: 1) normy rozwojowe (zarówno cech somatycznych, jak fizjologicznych i motorycznych) opracowywane na użytek szkolnictwa, slużby zdrowia, kultury fizycznej, przy czym celowe byloby wdrażanie prac rutynowych, których wynikiem byloby okresowe ich weryfikowanie i nowelizowanie (np. w cyklu 10letnim), 2) ekspertyzy o biologicznym stanie populacji przygotowywane w cyklu np. 10-letnim dla organów kierowniczych państwa, jako pomocnicza informacja przy programowaniu polityki spolecznej, 3) opracowywanie okresowych weryfikacji standardów odzieży i innego sprzętu masowego spożycia dla jednolitych dużych ludzkich zespolów (wojsko, szkolnictwo), 4) przygotowywanie doraźnych ekspertyz o przemianach biologicznych regionalnych populacji, wobec narastajacych ekologicznych zagrożen. Prace te mogą i powinny być realizowane w ścislym wspóldzialaniu $z$ innymi dyscyplinami naukowymi, lecz przy zachowaniu znaczącej roli antropologi" [BERGMAN $i$ in. 1985]. 
Czym może antropologia służyć innym dyscyplinom

Odpowiedzi na to pytanie udzielaliśmy już wyżej, omawiając aktualny stan badań polskiej antropologii oraz ich prawdopodobne kierunki. Wolno nam zatem dokonać tylko podsumowania odpowiedzi. Współdzialającym dyscyplinom naukowym służy antropologia: a) metodami badawczymi przydatnymi do pomiaru i analizy morfologii ludzkiego ciala, a także jego różnych funkcji, do oceny biologicznego rozwoju osobnika oraz zmian biologicznych zachodzących w jego organizmie pod wplywem różnych bodźców szeroko rozumianego środowiska; b) dostarcza syntetycznych informacji o procesie osobniczego rozwoju - szczególnie bjologicznego - oraz jego różnych uwarunkowań; c) przedstawia informacje o biologicznych zmianach przystosowawczych do różnych form aktywności fizycznej i spolecznej; d) dostarcza informacji o biologicznych skutkach różnych spolecznych procesów. Może więc antropologia stwarzać przeslanki racjonalizacji różnych decydujących poczynań.

\section{Miejsce antropologii w nadchodzącej cywilizacji XXI wieku}

Podejmijmy próbę odpowiedzi na ostatnie z postawionych pytań, dotyczące miejsca, celów i zadań antropologii w spoleczeństwie nadchodzącego XXI wieku. Należaloby sięgać do rozleglych rozważań futurologicznych, będących przedmiotem wielu naukowych dyscyplin, pomijając publicystyczne dywagacje. W materialach antropologicznych znajdujemy rozważania i formulowane poglądy dotyczące informacji o przyszłych losach czlowieka i ludzkiej populacji, lecz sama dyscyplina nie dysponuje spojrzeniem dostatecznie dokumientowanym na swój wlasny rozwój. Można by zatem do zadań wyżej już formulowanych dopisać jeszcze jedno: zrealizować ogólnośodowiskową dyskusję na temat przyszlych losów polskiej antropologii i odpowiednio do jej wyników zarysować perspektywiczne, o odleglym horyzoncie czasowym, plany rozwoju.

Wracając do próby odpowiedzi na postawione pytanie należy - choćby w najogólniejszej formie - wskazać na niektóre tendencje rozwoju ludzkiej spoleczności, gdyż one będą ustalaly miejsce naszej dyscypliny w nadchodzących latach. Ze znacznym uproszczeniem można je sprowadzić do następujących [DROZDOwSKI 1983b]: 1) zmienia się charakter pracy zawodowej, z której coraz bardziej eliminuje się prostą pracę fizyczną, wprowadzając na jej miejsce dzialania w znaczniejszym stopniu obciążające uklad nerwowy, aniżeli uklad ruchu, staje się ona także jednostronna, obciążająca tylko niektóre części organizmu, 2) postępująca urbanizacja, związana z dynamicznie rozwijającym się przemyslem, prowadzi do niszczenia naturalnych środowisk, w ich miejsce powstają mikrośrodowiska, które na ogól niekorzystnie oddziałują na ludzki organizm, prowadzą do rozrywania naturalnych biospolecznych struktur, a w ich miejsce nowe układy zaczynają dopiero wchodzić, przy czym ich biologiczna i spoleczna wartość nie są jeszcze znane, 3) następuje ograniczenie spontanicznej aktywności ruchowej, która jest zastępowana formami sztucznymi bądź przyjmującymi postać zwyrodnieniową, 4) zagrożenie i niszczenie natrualnego środowiska lącznie z jego integralną częścią skladową, jaką jest czlowiek i ludzka populacja . stwarza konieczność uruchomienia 
czynników przeciwdzialających zarówno powstającej patologii biologicznej (np. schorzenia ukladu krążenia, wypadki w czasie pracy i komunikacyjne, otyłość, nerwice itp.), jak też spolecznej (anarchizowanie środowisk, terroryzm, spoleczna znieczulica itp.), zresztą wzajemnie się niejednokrotnie przeplatających i warunkujących, 5) upowszechniające się ksztalcenie oraz wydłużanie czasu jego trwania. Należaloby jeszcze dodać powstawanie warunków do zwiększonej chłonności czlowieka na informacje związane nie tylko $z$ jego zawodowym przygotowaniem, lecz także narastanie wymiaru tzw. "wolnego czasu", którego wypelnienie będzie nieodzowne.

W materialach Wydzialu II Nauk Biologicznych PAN na III Kongres Nauki Polskiej, mówiących o biologii nadchodzących lat, znajdujemy następujące stwierdzenie [Materialy ... 1985]; "Czlowiek wspólczesny wiąże wiele swych oczekiwań z postępem nauk biologicznych. Wyżywienie wzrastającej masy ludności (a może także kontrola biologiczna procesów demograficznych?), zwalczanie chorób nowotworowych i zagrożeń środowiskowych - oto kilka podstawowych problemów, w rozwiązaniu których mogą pomóc dalsze postępy nauk biologicznych. (...). Strategicznym zadaniem nauk biologicznych na obecnym etapie ich rozwoju jest więc dokonanie radykalnej przemiany w podstawach materialnego bytu czlowieka, jego stosunku do przyrody poprzez biologizację technologii oraz ekologizację produkcji przemyslowej i rolniczej". Można sądzić, że w tak określonym strategicznym zadaniu nauk biologicznych zawiera się znaczna część podstawowej formuly cywilizacji XXI wieku. Płyną stąd zadania także dla antropologii.

Sądzę, że w nadchodzących dziesięciole ciach trzeba będzie zintensyfikować wysi- lek dla pelnego poznania biologicznych skutków spolecznych przemian zachodzących w ludzkiej - szczególnie polskiej populacji, zarówno tych doraźnych, będących wynikiem okresowych fluktuacji różnych spolecznych procesów, jak też dlugotrwalych, związanych z ogólnoświatowymi tendencjami rozwoju wspólczesnej cywilizacji. Wyżej przytaczaliśmy kwestie opracowywane przez polską antropologię. Uzyskane wyniki trzeba będzie spiesznie przekształcić w zespół dwojakich informacji: różnego rodzaju ekspertyzy dla kierowników zespołowych i indywidualnych spoleczno-gospodarczego życia $w$ naszym kraju oraz w określonym stopniu spopularyzowane informacje udostępnione w szerokim zakresie spoleczeństwu. Należy podkreślić, że już obecnie występuje znaczne zainteresowanie spoleczeństwa tą problematyką, stąd jest konieczne upowszechnianie (różnymi drogami i w różnych formach) najnowszych polskich i światowych wyników badań związanych $z$ problematyką antropologiczną.

Nastąpi niewątpliwie nawrót do ściślejszych powiązań antropologii $\mathrm{z}$ naukami spolecznymi, a mamy w tym względzie dobre tradycje z okresu najbardziej burzliwego rozwoju dyscypliny oraz tworzenia podstaw i rozwijania Polskiej Szkoly Antropologicznej. Niezależnie od niektórych koniunkturalnych sytuacji, proces przywracania tych nawiązań jest nieodzowny wobec konieczności szerszego uwzględniania spolecznej komponenty wśród rozlicznych czynników wyznaczających rozwój czlowieka i ludzkiej populacji.

Swoimi działaniami, przedstawianymi wynikami badań może antropologia przyczynić się do: 1) oszczędności ludzkiej biologicznej substancji w wyniku racjonalizacji doboru kandydatów do różnych form fizycznego wysilku i stworzenia przesłanek 
dla systemu "wczesnego ostrzegania" w wyniku kontrolnych badań biologicznych skutków zawodowej dzialalności; 2) ulatwienia ludzkiej pracy poprzez stworzenie morfofunkcjonalnych podstaw wlaściwego, czy choćby tylko bardziej racjonalnego, zagospodarowania przestrzeni pracy; 3) określonych materiałowych i energetycznych oszczędności wynikających $z$ wdrażania przedstawianych opracowań na użytek przemyslu; 4) obiektywizacji opinii organów doradczych oraz decyzji organów kierowniczych dotyczących spoleczno-gospodarczej polityki kraju, wobec wykorzystywania informacji o stanie i tendencjach przemian w biologicznej wartości polskiej populacji, jej różnych regionalnych i społecznych, a także zawodowych grup.

\section{Zakończenie}

Kończąc nasze rozważania o celach i zadaniach antropologii w rzędzie innych nauk oraz jej zastosowaniach, należy zdać sobie sprawę $z$ jej istoty jako nauki. $T$. KOTARBIŃSKI [1965] mówi, że "termin nauka mieni się barwami czworakiej wieloznaczności. Znaczy on bowiem tyle co badanie określonego rodzaju, bądź tyle co nauczanie, bądź tyle co uczenie się, a wreszcie bywa też nader często nazwą systemów twierdzeń należycie uzasadnionych". Naszymi rozważaniami staraliśmy się udokumentować miejsce antropologii w obszarze ludzkiej wiedzy, jej wkład do niej oraz spoleczną użytecność zarówno w procesach szeroko rozumianej edukacji, jak też możliwości spoleczno-gospodarczych zastosowań. Nie uzurpujemy sobie prawa do wyczerpującego i zamykającego ujęcia rozważanych kwestii, co zresztą nie jest możliwe wobec ciaglego rozwoju obiektywnie istniejącej rzeczywistości. Jeżeli jednak nasze rozważania pobudzą teraz bądź w bliskiej przyszłości dyskusję kierunkującą rozwój dyscypliny - możemy uznać nasze zadanie za wypelnione wobec postawionych zadań. Niech nam zatem będzie wolno w zakończeniu nawiązać do wielokrotnie już przywolywanego materiału dla III Kongresu Nauki Polskiej, gdzie czytamy: "Rozwój naukowej dyscypliny nie odbywa się $w$ spolecznej próżni. Jest on uzależniony między innymi od ogólnej sytuacji spolecznej i ekonomicznej, jaka panuje w kraju, a także od tendencji rozwoju nauk w środowisku rodzimym i międzynarodowym. W naszym przekonaniu obecna sytuacja spolecznoekonomiczna tak Polski, jak świata, stwarza dla antropologii wyjątkowo ważne problemy badawcze, a zmiany zachodzące w ludzkiej populacji są niepowtarzalne. Ich zarejestrowanie, poznanie mechanizmów, stwarza podstawę nie tylko przyszlych prac badawczych, lecz również ważnych społecznie organizacyjnych rozwiązań i poczynań. Pelne wykorzystanie tej sytuacji jest obowiązkiem nie tylko antropologicznego środowiska".

\section{Piśmiennictwo}

BERGMAN P., Z. DROZDOWSKI, T. KRUPIŃSKI, A. MALINOWSKI, 1985, Giówne kierunki rozwoiu polskiej ansropologii w lasach 1985-2000, (maszynopis), Poznań.

BIELICKI T., 1969, Niektóre zwiqzki zwrosne w procesie ewolucji Hominidae, Mat.Pr. Antrop., 77, 3.

BIELICKI T., 1981, Niektóre antropologiczne przejawy rozwarstwienia spolecznego wspóiczesnej ludności Polski, Kosmos, 561.

BIELICKI T., 1984, "Światopogląd naukowy" $i$ naczelne wartości ludzkiego tycia; harmonia czy dysonans, [w:] Wizje czlowieka i spoleczenistwa w teoriach ibadaniach naukowych, S. Nowak red., Warszawa, 188. 
CZEKANOWSKI J., 1930, Zarys antropologii Polski, Lwów.

CZEKANOWSKI J., 1948a, Aniropologia polska w międzywojennym dwudziestoleciu 1919-1939, Warszawa

CZEKANOWSKI J., 1948b, Zagadnienia antropologii. Zarys antropologii teoretycznej, Toruń.

DROZDOWSKI Z., 1973, Sian i perspektywy rozwojowe nauk antropologicznych, Mat. II Kongresu Nauki Polskiej, sekcja Nauk Biol., Warszawa.

DROZDOWSKI Z., 1979, Antropologia w zakresie studiów wychowania fizycznego, Prz. Antrop., 45, 192.

DROZDOWSKI Z., 1980, Kultura firyczna i jej teoretyczne podstawy w kszlattowaniu wspolczesnego spoleczenstwa, Monogr. AWF w Poznaniu, 194, 11.

DROZDOWSKIZ., 1983a,Antropologiapolska -jejwkladdo teorii ipraktyki kultury fizycznej, Wych. Fiz. i Sport, 3, 3.

DROZDOWSKIZ., 1983b,Antropologia sportowa w Polsce, Prz. Antrop., 49, 213.

DROZDOWSKI Z, 1983c, Antropologia sportowa - cele $i$ zadania w swiesle aktualnych tendencji rozwoju kultury fizycznej, Roczn. Nauk. AWF w Poznaniu, 32, 27.

DROZDOWSKIZ., T. DZIERŻYKRAY-ROGALSKI, 1982, Kierunki i tendencje rozwoju antropologii polskiej, Prz. Antrop., 48, 67.

DROZDOWSKI Z., T. KRUPIŃSKI,J. STRZALKO, 1984, Antropologia polska 82, Prz. Antrop., 49, 241.

DZIERŻYKRAY-ROGALSKI T., J. CHARZEWSKI, 1978, 25 las Komiretu Antropologii Polskiej Akademii Nauk (1952-1977), Nauka Polska 26, 95.

DZIERŻYKRAY-ROGALSKI T., 1978, Znaczenie badan paleoantropologicznych dla antropologii, Prz. Antrop., 44, 389.

GOD YCKI M., 1959, Antropologiaw wychowaniu fizycznym. 40 lat od Katedry WF UP do WSWF w Poznaniu, Poznań

GLADYKOWSKA-RZECZYCKA J., 1979, Paleopatologia w Polsce, Prz. Antrop., 48, 392.

HENNEBERG M., 1978, Uwagi o motliwosci przyrodniczej interpretacji funkcjonowania populacji ludzkich, Prz. Antrop., 44, 188.

KOTARBIŃSKI T., 1965, Przeglqd problemów nauki o nauce, Zagadnienia Naukoznawstwa, z. 2-3.

LEVIN M. G., J. J. ROGINSKIJ, 1951, Osnovy antropologii, Moskva.

MALINOWSKI A. (red.), 1976, Badanie populacji ludzkich na materialach wspólczesnych $i$ hisforycznych, Poznań

MALINOWSKI A., 1979, Aktualnośc antropologii w procesie dydaktycznym szkół wyższych, Prz. Antrop., 45, 115.

Materialy do synterycznego opracowania Wydziahu Nauk Biologicznych PAN "Nauki biologiczne na III KNP", (maszynopis), Warszawa.

MYDLARSKI J., 1952, O nowe oblicze polskiej antropologii, Prz. antrop., 18, 1.

MYDLARSKI J., 1951, Niedomagania w rozwoju antropologii polskiej w międzywojennym dwudziestoleciu - stan jej obecny - i perspektywy na przyszlosk, Prz. Antrop., $17,1$.
Nauczanie antropologii i elementów biologii $w$ wyzszych uczelniach w Polsce. Materialy z sympozjum, 1979, Prz. Antrop., 45, 113.

Nauki antropologiczne w swietle uchwal II Kongresu Nauki Polskiej - stan realizacji, 1979, (maszynopis), Warszawa.

NOWAK L., 1978, Humanistyka a przyrodoznawstwo. Próba analizy programu antynaturalistycznego, Prz. Antrop., 44, 119.

PIASECKI E., 1977, Demograficzne przeslanki do badan w aspekcie generyki populacyjnej, Prz. Antrop., 43, 309.

PIONTEK J., 1978, Uwagi o metodologicznych aspektach badat przemian biologicznych populacji pradziejowych, Prz. Antrop., 44, 213.

PIONTEK J., 1979, Procesy mikroewolucyjne w europejskich populacjach ludzkich, Poznań.

PIONTEK J., 1985, Biologia populacji pradziejowych, Poznań.

SEDLAK W., 1980, Antropologia dynamiczna w bioelektronicznej perspektywie, Prz. Antrop., 46, 315

Sprowozdanie z drialalnosci Komisetu Antropologii Polskiej Akademii Nauk w latach 1975-77, (maszynopis), Warszawa.

Stan antropologii w Polsce i perspektywy rozwoju. Raport Komitetu Antropologii dla II Wydzialu Nauk Biologicznych PAN, (maszynopis), 1977, Warszawa.

STESLICKA-MYDLARSKA W., 1976, Aktualna dokumentacja paleontologiczna teorii antropogenery, Prz. Antrop., 42, 185.

STRZAZKO J., 1978, Kullura jako whaśiwośs sysiemów ¿ywych, Prz. Antrop., 44, 175.

Strzarko J., M. HenNeberG, J. Piontek, 1980, Populacje ludzkie jako systemy biologiczne, Warszawa.

STRZAZKO J., 1980, Antropologia z ekologicznego punktu widzenia. Niektóre problemy metodologii badari, Wiadomosci Ekolog. 26, 109.

WIATR J., 1985, Dokqd zmierza swiarowa politologia, Kultura, 10.

WIERCIŃSKI A., 1980, Treść antropologii, jej zakres $i$ znaczenie dla filozofii, Prz. Antrop., 46, 309.

WIERCIŃSKI A., 1984, Antropologiczne ujęcie kulury $i$ ewolucji kulturowej, [w:] Wizje czlowieka i spoleczenstwa w teoriach ibadaniach naukowych, S. Nowak red., Warszawa.

WOLAŃSKI N., 1975, Zagadnienie zagroteń organizmu czlowieka i populacji ludzkich przed ubocznymi skutkami cywilizacji, Kosmos, 6, 593.

WOLAŃSKI N., (red.), 1981, Czynniki rozwoju człowieka. Wstep do ekologii czlowieka, Warszawa.

WRZOSEK A., 1926, Zadania wspótczesnej antropologii Prz. Antrop., 1,3, Czlowiek jego rasy i tycie, 1938 , Warszawa, t.1.

Referat wygloszony na Konferencji Antropologicznej w Blażejewku, we wrześniu 1985 r. 
An analysis and evaluation has been made of the present investigation directions of the Polish anthropology, world tendencies of the development of this discipline and the expected social needs. This permitted to divide the main directions of anthropological studies into the following ones:

1) In the field of methods and investigation techniques we can expect the implementation of different methods of the investigation on biochemical properties of the human organism, different internal organs in vivo (radiological and tomographic techniques), and also sociometric techniques. A further computerization will follow both in the process of the accumulation of anthropological information data and their processing.

2) Onthogenetic studies will be concentrated around the problem of biological value of Polish population and its conditioning by the changing environmental factors. More intensive investigation will be carried out on the productivity period of human life and the senile period with a wider consideration of the functional properties. Studies on biological conditionings and results of different phenomena in the individual development process of man will be extended.

3) Studies on the morphofunctional conditionings of the physical activity of man will be developed. Investigations in this field should supply information about biosocial prerequisites of the matching and selection in different forms of motor activity of man, both the professional and those connected with different fields of physical culture. It creates the basis of compensating activity, particularly compensating the negative results.

4) The traditional Polish studies in the field of ethnical anthropology will be more and more concentrated around the problem of the biology of the prehistoric populations and the process of ethnogenesis. They should lead to the understanding of the structure of the extinct populations and their living conditions, the cognition of the microevolutional transformations of man, and also their conditionings. It will permit a reconstruction of the living environment of our ancestors, their mode of living and on this background of the biological transformations of population.

5) Studies on the philogenesis of man will probably still move in the direction of general theory of anthropogenesis with the utilization of the investigation methods characteristic of Polish anthropology.

6) In the field of the practical application of anthropology we should expect a continuation or undertaking of studies on: a) developmental norms both of the somatic features and the physiological and motoric features, b) cyclical expertises referring to the biological conditions of population, c) periodical verification of the standards of clothes and other equipment of mass consumption, d) sporadical expertises on different biosocial situations in the regional populations in connection with the growing ecological endangerment. 